\title{
ЕКСПЕРИМЕНТАЛЬНІ ДОСЛІДЖЕННЯ РОБОТИ СТЕРЖНЕВОЇ АРМАТУРИ В ПЕРЕРІЗАХ КОМБІНОВАНО-АРМОВАНИХ НЕРОЗРІЗНИХ ЗАЛІЗОБЕТОННИХ БАЛОК
}

\author{
EXPERIMENTAL RESEARCHES OF THE WORK OF STEEL REBAR \\ IN THE CROSS-SECTIONS OF CONTINUOUS COMBINED- \\ REINFORCED CONCRETE BEAMS
}

\begin{abstract}
Андрійчук О.В., к.т.н., доц. (Луцький національний технічний університет), Нінічук М.В. аспірант (Луцький національний технічний університет)
\end{abstract}

Andriichuk O.V., Ph.D., associate professor, (Lutsk National Technical University), Ninichuk M.V., postgraduate student (Lutsk National Technical University)

Анотація. Проведено аналіз експериментальних досліджень особливостей роботи стержневої арматури в перерізах двопролітних залізобетонних балок. При їх конструюванні в якості армування використовується класична сталева арматура у вигляді каркасів, та дисперсне армування бетону сталевою фіброю.

Summary. Perspective direction of concrete structures improvement are increasing their strength, hardness and shear strength by using statically indeterminate structures. Special place is occupied by statically indeterminate (continuous) reinforced concrete beams, as they most efficiently used components materials - concrete and reinforcement. The dispersed-reinforced materials, including steel fibrous concrete are the one of most promising structural materials that can increase the compressive strength of concrete materials and structures, tensile strength, shear strength, get effective structures which would respond to higher operational requirements. The article presents the results of experimental studies of the work of steel rebar in cross sections of two-span reinforced concrete beams in which classical rebar frames and dispersed reinforcement of concrete with steel fibers are combined.

Experiments were conducted with $300 \mathrm{~cm}$ long two-span beams which were made from heavy concrete The size of the cross section was $10 \times 16 \mathrm{~cm}$. The length of spans was $140 \mathrm{~cm}$. The additional, dispersed reinforcement of the test specimens was performed by using steel fibers, in a such way, that the specimens had different filling by the fibers volume of the beam, but with the same relative percentage of reinforcement, equal to $\mu=1 \%$. Thus, the beam 3B-1 was reinforced with fiber throughout its volume, $3 B-2-$ in stretched zones, 3B-3-to the height of the two minimum concrete cover zones.

During the testing in special flexural testing frame, was determined deflections, reinforcement and concrete strains, crack width. The load was accepted as fracture, when the strain of reinforcement or concrete reached the limit values. In the course of the research, the new experimental data were obtained, on the basis of which it can be concluded, that the use of additional disperse reinforcement of steel fibers of the 
stretched zones of continuous reinforced concrete beams, allows to decrease the reinforcement strains, enhance the strength and redistribution off the efforts in spans.

Ключові слова: бетон, сталева фібра, СФБ, арматура, деформації, напруження.

Keywords: concrete, steel fiber, SFRC, reinforcing bar, strain, stress.

Постановка проблеми. В сучасному будівництві досить широко застосовуються статично невизначені залізобетонні конструкції, зокрема багатопролітні нерозрізні залізобетонні балки. Вони $\epsilon$ складовими конструкцій перекриття промислових та цивільних будівель, шляхопроводів, естакад, мостових конструкцій. Як нерозрізні балки можна розглядати і стрічкові фундаменти під ряди колон, в тому числі i перехресні. Такі балки мають ряд переваг перед розрізними: менші витрати матеріалів, оскільки в перерізах виникають менші згинальні моменти; спрощене армування; підвищена жорсткість; відсутність стиків.

Для конструювання та виготовлення залізобетонних конструкцій у наш час актуальним $є$ застосування дисперсного армування, зокрема сталефібробетону, а також комбінованого армування (поєднання класичного армуванням із дисперсним). Суттєва перевага цього композитного матеріалу - його висока питома міцність на одиницю маси. Сталефібробетон краще опирається виникненню та розвиткові мікро- i макротріщин, витриваліший до вібраційних та ударних впливів, має підвищену міцність на стирання, вищу в'язкість і пружність тощо [1 - 3]. Ефективність застосування сталефібробетону (СФБ) в будівельних конструкціях може досягатися за рахунок зниження трудовитрат на арматурні роботи, суміщення технологічних операцій на приготування, армування, укладання та ущільнення СФБ суміші, продовження терміну експлуатації конструкцій і зниження витрат на різні види поточного ремонту.

Аналіз відомих досліджень і публікацій. Дослідження роботи нерозрізних залізобетонних конструкцій та вивчення їх напруженодеформованого стану проводились багатьма вченими. Багато робіт по дослідженню перерозподілу зусиль в нерозрізних балках було виконано в середині XX-го століття такими вченими як О.О. Гвоздєв, С.М. Крилов, A.I. Мангушев. та інші. В наш час актуальним $є$ обгрунтування та розробка деформаційних умов розрахунку нерозрізних балок, зокрема Бабичем В.С. була розроблена методика визначення напружено-деформованого стану i міцності нормальних перерізів балок на основі деформаційної моделі [4]. Активно проводяться дослідження роботи сталефібробетонних та комбіновано-армованих залізобетонних конструкцій. Вченими Бабичем Є.М., Андрійчуком О.В., Білозіром В.В., Дробошинцем С.Я. проведено багато досліджень особливостей роботи сталефібробетонних i 
сталефіброзалізобетонних згинальних елементів, розроблені методики визначення їх напружено-деформованого стану і міцності при дії одноразових та повторних (малоциклових) навантажень [5 - 6].

Варто відмітити, що вплив дисперсного армування сталевими фібрами на напружено-деформований стан, міцність, тріщиностійкість та перерозподіл зусиль статично невизначених залізобетонних конструкцій, $\epsilon$ маловивченим, тому результати експериментальних досліджень, що розглядаються у статті, $є$ актуальними на даний час.

Мета статті: встановити особливості роботи стержневої арматури в перерізах нерозрізних залізобетонних балок, у яких в якості армування використовується поєднання класичної сталевої арматури у вигляді каркасів та дисперсного армування бетону сталевою фіброю.

Методика експериментальних досліджень. Для встановлення впливу армування сталевими фібрами комбіновано-армованих залізобетонних нерозрізних балок на роботу стержневої арматури було проведено випробування трьох дослідних зразків. Вони являли собою нерозрізні двопрольотні залізобетонні балки довжиною 300 см з розмірами поперечного перерізу 10×16 см і довжиною прольотів по 140 см.

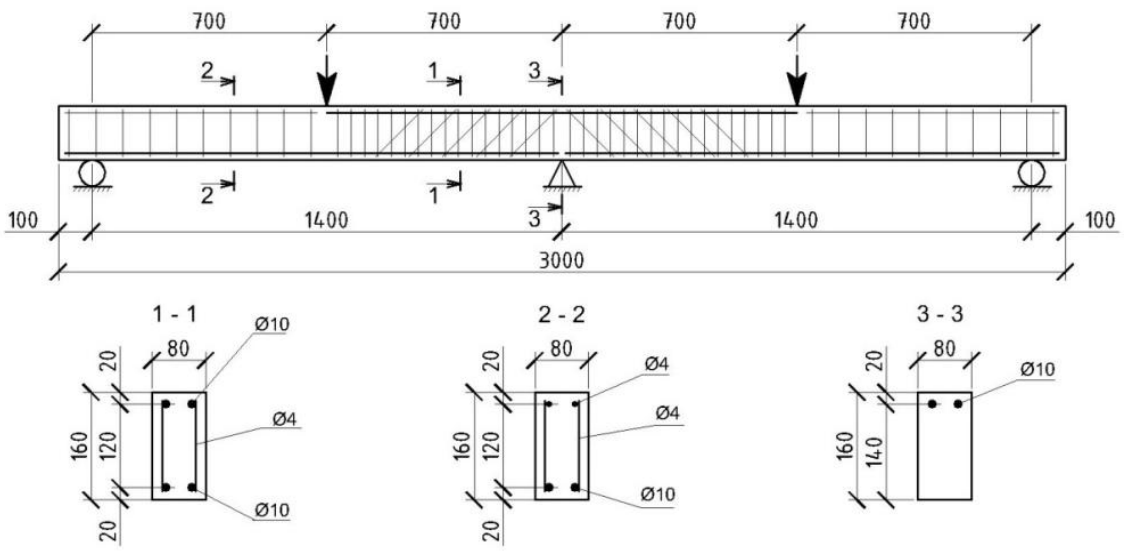

Рис.1. Конструктивна схема дослідних балок

Склад цементно-піщаної матриці прийнято 1:2. Використовували портландцемент марки М500 та попередньо відмулений від глинистих, пилуватих і мулистих домішок пісок 3 модулем крупності 2,4. Одночасно 3 виготовленням балок бетонували куби розміром $15 \times 15 \times 15$ см та призми $15 \times 15 \times 60 \mathrm{~cm}$, і $10 \times 10 \times 60 \mathrm{~cm}$, які використовувалися для визначення кубикової та призмової міцності бетону та його деформаційних характеристик. Цементно-піщана матриця мала такі механічні 
характеристики: середня кубикова міцність $f_{c m, c u b e}=33$ МПа; призмова міцність $f_{c m, p r i s m}=22,6 \mathrm{MПа,} \mathrm{міцність} \mathrm{на} \mathrm{розтяг} f_{c t}=0,5 \mathrm{MПа}$.

Основне армування виконувалось у вигляді двох плоских каркасів 3 робочою арматурою в прольотах і над опорою з Ø10А500С (підбиралась із врахуванням перерозподілу зусиль) і поперечним армуванням стержнями зі сталі Ø4Вр-I, які влаштовувались між середньою опорою і місцем прикладення зусилля 3 кроком 40 мм, а між крайньою опорою і місцем прикладення зусилля з кроком 80 мм (представлено на рис. 1).

Додаткове, дисперсне армування дослідних зразків виконувалося із застосуванням сталевих фібр таким чином, щоб у зразках було різне заповнення фібрами об'єму балки, але з однаковим відносним відсотком армування, рівним $\mu=1 \%$. Так, балка 3Б- 1 армувалася фібрами по всьому своєму об’єму, ЗБ-2 - у розтягнутих зонах, 3Б-3 - на висоту подвійного захисного шару бетону (рис. 2).
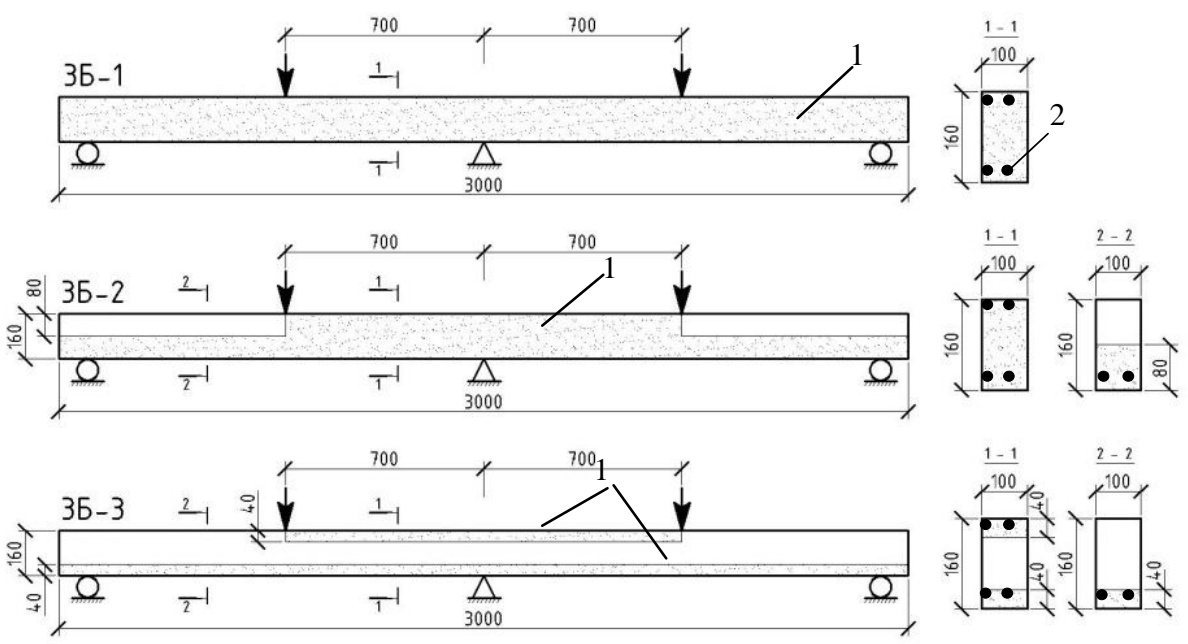

Рис. 2. Розподіл фібр по об'єму в зразках:

1 - зона додаткового армування фібрами, 2 - основна арматура

Використовувалися сталеві фібри хвилястої форми, довжиною 50 мм і діаметром 1 мм. Кубикова міцність СФБ була всього на 3\% більша, ніж цементно-піщаної матриці, і становила $f_{c m, c u b e}=34 \mathrm{MПа,} \mathrm{призмова} \mathrm{міцність}$ $-f_{\text {cm,prism }}=23,2 \mathrm{MПа,} \mathrm{міцність} \mathrm{на} \mathrm{розтяг}-f_{c t}=1,7$ МПа, що на $340 \%$ більше, ніж міцність на розтяг цементно-піщаної матриці.

Суміш для експериментальних зразків виготовлялася у бетонозмішувачі, а ущільнення проводилось за допомогою глибинного вібратора. Запланований розподіл фібр по об'єму здійснювався через 
пошарове бетонування зразків. Перерва між вкладанням шару цементнопіщаної матриці і шару з додатковим армуванням фібрами становила не більше 20 хвилин. Розпалублювали балки через 7 діб, подальше їх зберігання відбувалося у вологому середовищі протягом 28 діб, після чого вони знаходились у приміщенні лабораторії.

Для випробування дослідних зразків-балок була запроектована i виготовлена спеціальна силова установка. Плоский поперечний згин у двопрольотних балках створюється за допомогою гідравлічного домкрата i металевої двотаврової балки-траверси, що передає від нього на дослідну балку дві одинакові симетрично розташовані відносно середньої опори на відстані 700 мм зосереджені сили, що контролювалися динамометрами.

Завантаження дослідних зразків відбувалось ступенями. Після кожного прикладання зусилля знімали покази приладів (рис. 3) і візуально оглядали балки. Прогини вимірювали за допомогою прогиномірів 6ПАО, які розміщувалися під зосередженими силами. Деформації крайніх волокон стиснутої та розтягнутої зон бетону вимірювали індикаторами годинникового типу МІГ-1 (на базі 100 мм) і за допомогою тензодатчиків на базі 50 мм ланцюжками через 20 мм. Деформації арматури визначали тензорезисторами (на базі 20 мм) і тензометричною станцією ВНП-8. За допомогою динамометра, що слугував крайньою опорою, фіксували значення опорної реакції. Процес тріщиноутворення досліджувався за допомогою мікроскопа МПБ-3. За руйнівне приймали навантаження, коли деформації арматури або бетону досягали граничних значень.

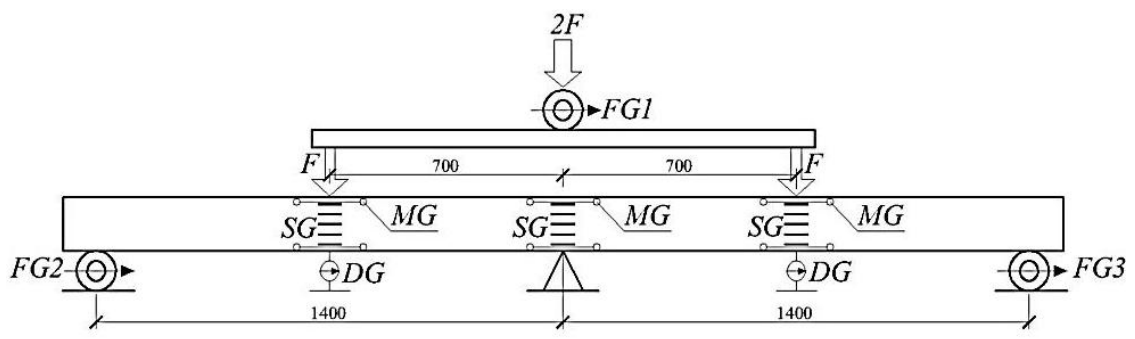

Рис. 3. Схема розташування вимірювальних приладів:

$F G$-динамометри; $S G$ - тензорезистори;

$D G$ - прогиноміри; $M G$ - індикатори годинникового типу

Також попередньо визначались механічні характеристики арматурних стержнів діаметром 10 мм. Випробувалось по три стержні довжиною по 50 см у розривній машині УИМ-50. Розтягувальні зусилля прикладалися ступенями, після яких робились витримки для зняття відліків по приладах.

Деформації кожного стержня вимірювали двома тензометрами Гугенберга на базі 20 мм 3 ціною поділок 0,001мм. Під час випробувань 
фіксувалася межа текучості та гранична міцність арматурних стержнів. За отриманими результатами випробувань побудовані діаграми деформування арматурних стержнів (рис. 4).

Випробовування стержнів засвідчили, що їх механічні характеристики перевищують нормативні значення для арматури класу А500C і не відповідають таким показникам арматури класу А600С. Так, для стержнів діаметром 10 мм отримані такі характеристики: межа міцності $\sigma_{u d}=754,8 \mathrm{MПа;} \mathrm{межа} \mathrm{текучості} \sigma_{y}=615,1$ МПа; модуль пружності $E_{s}=195997,8$ МПа, максимальні зафіксовані деформації арматури, які відповідають напруженням $\sigma_{y}, \varepsilon_{s 0}=314,2 \times 10^{-5}$.

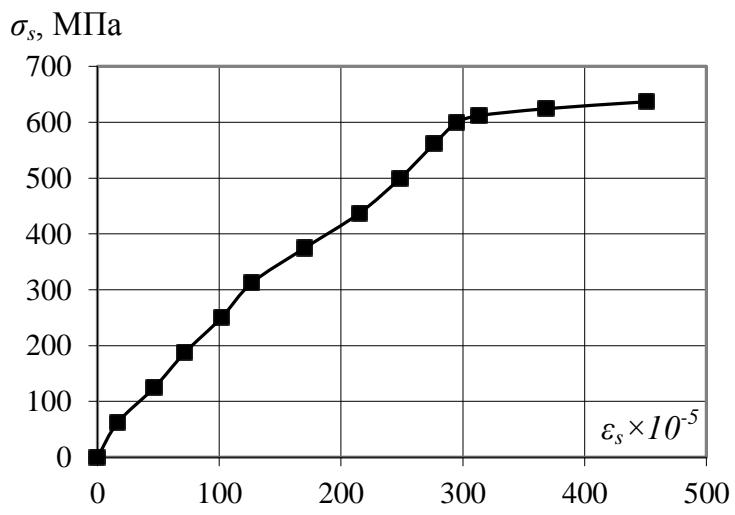

Рис. 4. Діаграма деформування арматурних стержнів діаметром 10 мм

Результати експериментальних досліджень. У процесі досліджень балок до руйнування були зафіксовані характерні особливості їх напружено-деформованого стану, що описано в роботах $[7,8]$ Так, всі балки зруйнувалися за нормальними перерізами внаслідок досягнення граничних деформацій арматури в прольотах і над опорою, а також граничних деформацій бетону в стиснутих зонах. Руйнівне навантаження для випробуваних зразків-балок становило: для балки 3Б-1 $F_{u}=53 \mathrm{\kappa H}$, для балки 3Б- $2 F_{u}=52$ кН, для балки 3Б-3 $F_{u}=46$ кН.

У балці 3Б-1, яка була армована сталевими фібрами по всьому об'єму, перші тріщини виникли в поперечних перерізах на ділянках прикладання зосередженої сили при навантаженні $F=16$ кН. При цьому навантаженні ширина розкриття тріщин становила $a_{c r c}=0,08$ мм на опорі, та $a_{c r c}=0,05$ мм у прольотах а деформації в розтягнутій арматурі складали в прольотах $\varepsilon_{s, s p}=47,65 * 10^{-5}$, та $\varepsilon_{s, s u p}=70,21 * 10^{-5}$ над середньою опорою, що відповідає напруженням в арматурі $\sigma_{s, s p}=125,1 \mathrm{MПа} \mathrm{та} \sigma_{s, s u p}=186,2 \mathrm{MПа}$ відповідно. При навантаженні балки до $F=32$ кН деформації арматури збільшились до $\varepsilon_{s, s p}=112,54 * 10^{-5}$ та $\varepsilon_{s, s u p}=184,9 * 10^{-5}$, тобто порівняно 3 
першим ступенем навантаження вони зросли більше ніж удвічі, що свідчить про роботу балки на другому ступені навантаження з тріщинами в нормальних перерізах прольотів (рис. 5).

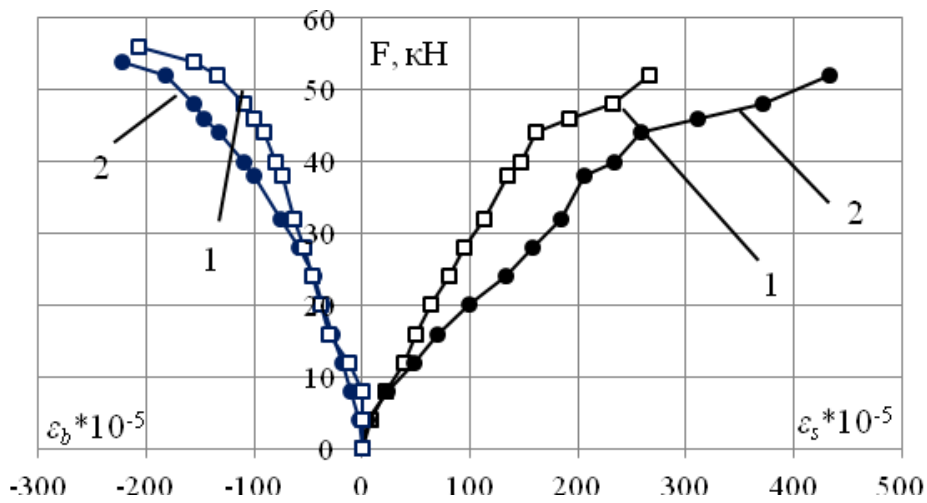

Рис. 5. Деформації арматури та стиснутої зони бетону в процесі випробувань балки 3Б-1: 1 - у прольотах; 2 - на опорі.

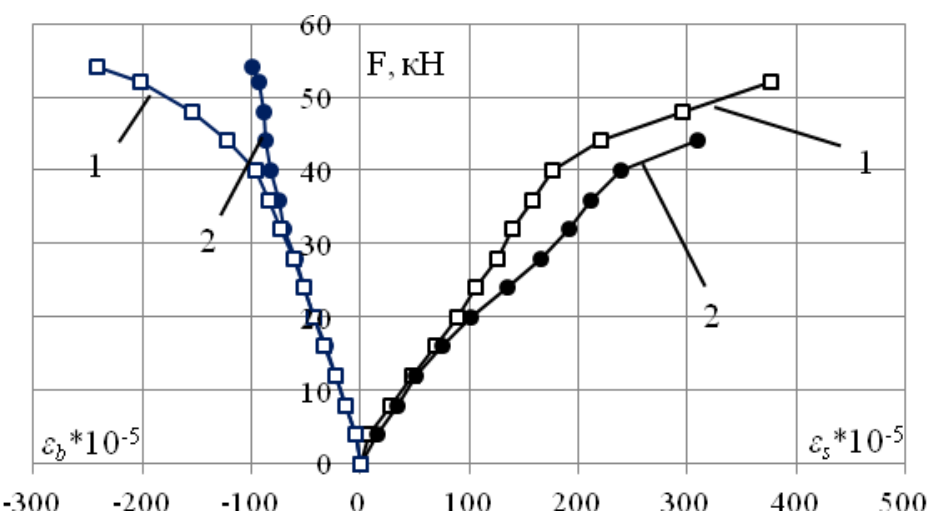

Рис. 6. Деформації арматури та стиснутої зони бетону в процесі випробувань балки 3Б-2: 1 - у прольотах; 2 - на опорі.

При порівняльному, для трьох балок, рівні навантаження $F=40$ кН, деформації арматури в опорному перерізі балки 3Б-1 становили $\varepsilon_{s, s u p}=233,7 * 10^{-5}$, а в прольотних перерізах $\varepsilon_{s, s p}=137,9 * 10^{-5}$, що відповідає напруженням в арматурі $\sigma_{s, s u p}=462,3 \mathrm{MПа,} \mathrm{та} \sigma_{s, s p}=325,4$ МПа. При рівні навантаження $F=48 \mathrm{\kappa H}$ деформації арматури в опорному перерізі 
перевищили граничні $\varepsilon_{s 0}=314,2 \times 10^{-5}$ і становили $\varepsilon_{s, s u p}=371,43 * 10^{-5}$, що свідчить про утворення пластичного шарніру над опорою внаслідок досягнення напружень в арматурі межі текучості.

При випробування балки ЗБ-2, яка була армована сталевими фібрами тільки у розтягнутих зонах, перші тріщини з'явилися вже при рівні навантаження $F=12$ кН. Ширина розкриття тріщин теж була дещо меншою і становила $a_{c r c}=0,07$ мм на опорі та $a_{c r c}=0,03$ мм у прольотах, а деформації арматури складали в прольотах $\varepsilon_{s, s p}=48,56 * 10^{-5}$ та $\varepsilon_{s, s u p}=$ $50,23 * 10^{-5}$ над середньою опорою. При подальшому навантаженні деформації розвивалися пропорційно і при значенні зосередженої сили в прольоті $F=40$ кН значення деформацій арматури досягли $\varepsilon_{s, s p}=177,02 * 10^{-5}$ та $\varepsilon_{s, s u p}=239,19 * 10^{-5}$, що на $28,2 \%$ та на $2,3 \%$ відповідно більше, ніж у балки 3Б-1. Досягнення стержневою арматурою в опорному перерізі межі текучості спостерігалося при рівні навантаження $F=46 \mathrm{\kappa H}$ (рис. 6). Процес розвитку тріщин і характер руйнування балки були такими, як балці 3Б-1.

У балці ЗБ-3, яка була армована сталевими фібрами на подвійну висоту захисного шару бетону, перша поява тріщин була зафіксована, як і у балці 3Б-2, на рівні навантаження $F=12$ кН. Деформації арматури в прольоті i на опорі становили відповідно $\varepsilon_{s, s p}=50,57 * 10^{-5}$ та $\varepsilon_{s, s u p}=47,26 * 10^{-5}$, тобто як і у балці $3 Б-2$ були практично однаковими (рис. 7).

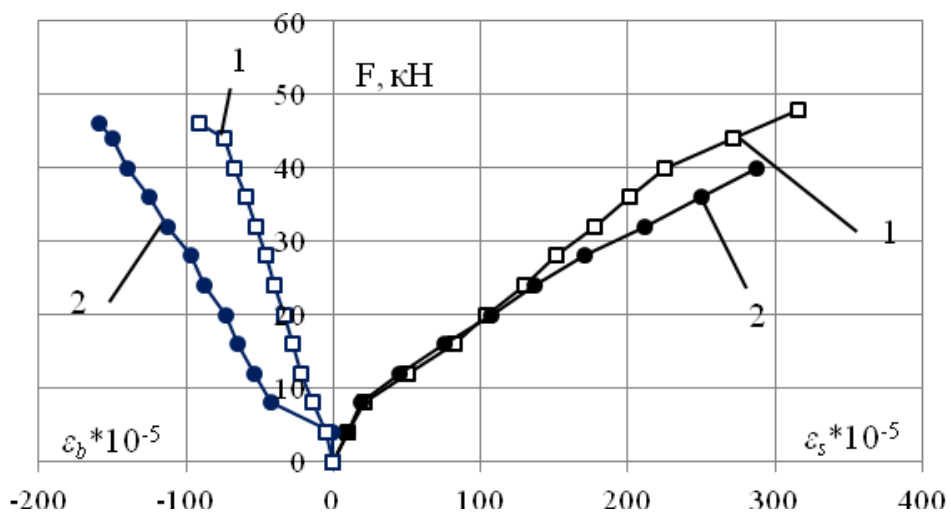

Рис. 7. Деформації арматури та стиснутої зони бетону в процесі випробувань балки 3Б-3: 1 - у прольотах; 2 - на опорі.

При навантаженні балки до порівняльного рівня $F=40$ кН деформації арматури збільшились до значень $\varepsilon_{s, s p}=224,58 * 10^{-5}$ та $\varepsilon_{s, s u p}=287,03 * 10^{-5}$, 
що на $62,7 \%$ та на 22,8 \% відповідно більше, ніж у балці 3Б-1 при такій же величині зосередженої сили в прольоті. Вже на наступному рівні навантаження, при $F=44 \mathrm{\kappa H}$, напруження в арматурі над середньою опорою досягли граничних значень і утворився пластичний шарнір, i практично відразу після цього, вже при навантаженні $F=46$ кН, відбулося повне руйнування балки внаслідок досягнення граничних деформацій арматури в прольотах і стиснутого бетону над центральною опорою.

Висновки. В ході проведених експериментальних досліджень були отримані нові експериментальні дані, на основі яких можна зробити висновки, шо використання додаткового дисперсного армування в нерозрізних залізобетонних балках дозволяє підвищити їх жорсткість та несучу здатність. Встановлено, що дисперсне армування сталевими фібрами розтягнутих зон балки призводить до зменшення напружень у стержневій арматурі та дозволяє уповільнити розвиток пластичних деформацій в арматурі під час перерозподілу зусиль у балці.

\section{References}

1. Borysiuk O. P. Napruzheno-deformovanyi stan zalizobetonnykh balok pidsylenykh pid navantazhenniam stalefibrobetonom i kompozytamy pry dii malotsyklovykh navantazhen / O. P. Borysiuk, Yu. Yu. Ziatiuk // Resursoeko-nomni materialy, konstruktsii, budivli ta sporudy: zb. nauk. prats. - Rivne : NUVHP, 2016. Vyp. 33. - S. 303-313.

2. Andriichuk $\mathrm{O}$. The impact of the reinforcement percentage on the stress-strain state of the bending steel fiber reinforced concrete elements/ Andriichuk O., Babich V., Yasyuk I., Uzhehov S. // MATEC Web of Conferences, N 230, p 02001 (2018), 1-5.

3. Andriichuk $\mathrm{O}$. The influence of repeated loading on work of the steel fiber concrete drainage trays and pipes on the roads / Andriichuk O., Babich V., Yasyuk I., Uzhehov S. // MATEC Web of Conferences, N 116, p 02001 (2017), 1-9.

4. Babych V.Ie. Napruzheno deformovanyi stan i mitsnist nerozriznykh zalizobetonnykh balok pry odnorazovykh ta povtornykh navantazhenniakh: avto-ref. dys. na zdobuttia nauk. stupenia kand. tekhn. nauk: spets. 05.23.01 «Budi-velni konstruktsii, budivli ta sporudy» / V.Ie.Babych - Poltava, 2005.- 16s.

5. Bilozir V.V. Vplyv nyzkhidnoi vitky diahramy deformuvannia stalefib-robetonu za roztiahu na nesuchu zdatnist balok / V.V. Bilozir // Visnyk Lvivskoho natsionalnoho ahrarnoho universytetu.- Dubliany, LNAU, 2015. Vypusk № 16. - S. 60 - 64.

6. Droboshynets S.Ia., Vplyv povtornykh malotsyklovykh navantazhen na mekhanichni kharakterystyky stalefibrobetonu ta robotu zghynalnykh eleme-ntiv na yoho osnovi / Dysertatsiia na zdobuttia naukovoho stupenia kandydata tekhnichnykh nauk. Lutsk LNTU, 2006. - S. 191.

7. Ninichuk M.V., Vplyv sposobu armuvannia stalevymy fibramy nerozri-znykh zalizobetonnykh balok na yikh napruzheno deformovanyi stan/ Resurso-ekonomni materialy, konstruktsii, budivli ta sporudy: Zbirnyk naukovykh prats. - Rivne: Vydavnytstvo Rivnenskoho derzhavnoho tekhnichnoho univer-sytetu, 2015. - Vypusk 31.

8. Ninichuk M.V., Vplyv kombinovanoho armuvannia na prohyny nerozri-znykh zalizobetonnykh balok/ Resursoekonomni materialy, konstruktsii, budi-vli ta sporudy: 
Zbirnyk naukovykh prats. - Rivne: Vydavnytstvo Rivnenskoho derzhavnoho tekhnichnoho universytetu, 2016. - Vypusk 32.

\section{Список використаної літератури}

1. Борисюк О. П. Напружено-деформований стан залізобетонних балок підсилених під навантаженням сталефібробетоном i композитами при дії малоциклових навантажень / О. П. Борисюк, Ю. Ю. Зятюк // Ресурсоекономні матеріали, конструкції, будівлі та споруди: зб. наук. праць. - Рівне : НУВГП, 2016. - Вип. 33. - С. 303-313.

2. Andriichuk $O$. The impact of the reinforcement percentage on the stress-strain state of the bending steel fiber reinforced concrete elements/ Andriichuk O., Babich V., Yasyuk I., Uzhehov S. // MATEC Web of Conferences, N 230, p 02001 (2018), 1-5.

3. Andriichuk $O$. The influence of repeated loading on work of the steel fiber concrete drainage trays and pipes on the roads / Andriichuk O., Babich V., Yasyuk I., Uzhehov S. // MATEC Web of Conferences, N 116, p 02001 (2017), 1-9.

4. Бабич В.С. Напружено деформований стан і міцність нерозрізних залізобетонних балок при одноразових та повторних навантаженнях: автореф. дис. на здобуття наук. ступеня канд. техн. наук: спец. 05.23.01 «Будівельні конструкції, будівлі та споруди» / В.С.Бабич - Полтава, 2005.- 16с.

5. Білозір В.В. Вплив низхідної вітки діаграми деформування сталефібробетону за розтягу на несучу здатність балок / В.В. Білозір // Вісник Львівського національного аграрного університету.- Дубляни, ЛНАУ, 2015. Випуск № 16. - С. $60-64$.

6. Дробишинець С.Я., Вплив повторних малоциклових навантажень на механічні характеристики сталефібробетону та роботу згинальних елементів на його основі / Дисертація на здобуття наукового ступеня кандидата технічних наук. - Луцьк ЛНТУ, 2006. - С. 191.

7. Нінічук М.В., Вплив способу армування сталевими фібрами нерозрізних залізобетонних балок на їх напружено деформований стан/ Ресурсоекономні матеріали, конструкції, будівлі та споруди: Збірник наукових праць. - Рівне: Видавництво Рівненського державного технічного університету, 2015. - Випуск 31.

8. Нінічук М.В., Вплив комбінованого армування на прогини нерозрізних залізобетонних балок/ Ресурсоекономні матеріали, конструкції, будівлі та споруди: Збірник наукових праць. - Рівне: Видавництво Рівненського державного технічного університету, 2016. - Випуск 32. 